"Transition in Printing" from the original typescript and a handlist of the University of California, Santa Barbara, Guthrie Collection by Christian Brun. The keepsake was designed and printed by Mr. William Horton and his Sun Press. Copies are being mailed to the Friends of the UCSB library.

- Xerox Corporation's University Microfilms has been named publisher of The International Microfilm Journal of Legal Medicine, a unique medical-legal journal which is distributed only in microimage form. Sponsored by the Milton Helpern Library of Legal Medicine, the journal is published quarterly on microfiche. Editor-inChief of the publication is Dr. Milton Helpern, Chief Medical Examiner of the City of New York. Annual subscriptions are $\$ 17.50$; single issues $\$ 5.00$.

- The Harvard Graduate School of Education, faced with the problem of improving its library facilities, convened a symposium on "Library Technology and Architecture." Six "consultants" contributed reports which formed the basis for an all day conference. The reports and conference transcript have been published in "Library Technology and Architecture, Report of a Conference at the Harvard Graduate School of Education, February 9, 1967." (Cambridge, Mass.: Library, Graduate School of Education, Harvard University, 1968. 51 pp. $\$ 1.00)$. Most attention was given to possible introduction of new library technology and methodology-decision areas which precede or should precede architectural design. The consultants whose reports are included were: Carl F. J. Overhage, Director, Project INTREX (INformation TRansfer EXperiment), Massachusetts Institute of Technology; Joseph Becker, Director of Information Sciences, EDUCOM, (Interuniversity Communications Council); Walter H. Kilham, Jr., O'Connor and Kilham, Architects, New York, N.Y.; Richard E. Schutz, Director, Southwest Regional Laboratory for Educational Research and Development; Richard C. Oldham, Assistant Director, Education Division, WGBH-TV Educational Foundation; Theodore R. Conant, Executive Producer, Education Division, WGBH-TV Educational Foundation.

- Brief descriptions in German and English of 55 mechanized systems and mechanization projects in West German documentation centers and libraries are contained in a new publication: Mechanization in Documentation in the Federal Republic of Germany. Third Compilation: Position as at 1st January 1968. The entries are arranged by subject fields. Libraries are listed separately. There is an index of institutions with addresses and a person index. Copies are available from Zentralstelle fŭr maschinelle Dokumentation, 6 Frankfurt am
Main, Holzhausenstrasse 44, West Germany. The price is about $\$ 2.00$.

- The Brazilian Institute of Bibliography and Documentation (IBBD) has issued a new edition of Periódicos Brasileiros de Cultura which lists 2,049 periodicals currently published in Brazil. To the extent the information was available to the Institute, each entry includes the name and address of the publisher, the year in which publication commenced, the frequency, and, for appropriate publications, in which index or bibliography it appears. Newspapers are not included, but a few of their regular supplements on special topics are. In addition to a subject index, there is also an alphabetical list of titles with reference to the numbered entry. More than 800 Brazilian publications that have ceased or suspended publication or that failed to respond to the Institute's questionnaire are listed separately. The Institute plans to publish supplements to this edition containing new serial titles, changes of title, publications that cease or suspend publication, and revisions, as necessary, of entries in the current edition. Copies of Periódicos Brasileiros de Cultura may be purchased at $\mathrm{NCr} 10,000$ each by writing to: Instituto Brasileiro de Bibliografia e Documentação, Avenida General Justo $171,4^{\circ}$. andar, Rio de Janeiro, Brazil.

\section{HIGHER EDUCATION ACT}

On October 1, the President signed H.R. 18037 (Public Law 90-557), the act making appropriations for the Departments of Labor and Health, Education, and Welfare. Included in the act is an appropriation of $\$ 5.5$ million for Title II-C of the Higher Education Act.

On October 16, the President signed S. 3769 (Public Law 90-575), the Higher Education Amendments of 1968. The law extends Title II, Part C (National Program for Acquisitions and Cataloging) of the Higher Education Act for fiscal year 1969 and the next two succeeding fiscal years. It authorizes an appropriation of $\$ 6$ million for fiscal year 1969 and $\$ 11 \mathrm{mil}$ lion for the next two years. In addition, this section of the Act was amended so as to give the Librarian of Congress authority to:

1. purchase additional copies of a single title of a book acquired through the Title II-C program.

2. provide not only cataloging information about currently acquired materials but also other aids to higher education, such as bibliographies, indexes, guides and union lists, describing not only current books but other important materials essential to research.

3. pay administrative costs of cooperative arrangements for acquiring for institutions of higher education or combinations thereof, library materials not readily obtainable outside the country of origin. 